\title{
GROWTH AND LONGEVITY OF THE INSECT PREDATOR, Sycanus dichotomus STAL. (Hemiptera: Reduviidae) FED ON LIVE INSECT LARVAE
}

\section{SITI NURULHIDAYAH AHMAD* and NORMAN KAMARUDIN*}

\begin{abstract}
The suitability of Tenebrio molitor Linn. (Coleoptera: Tenebrionidae) and Corcyra cephalonica Stainton (Lepidoptera: Pyralidae) larvae as food sources for the general insect predator, Sycanus dichotomus Stal. (Hemiptera: Reduviidae) was evaluated by examining the effects of different prey consumption on the predator's growth parameters and longevity. The growth parameters assessed in this study were developmental period, body weight and femur length. Compared to single prey species, a combination of prey consisting of C. cephalonica and T. molitor larvae generally increased the growth and development of nymphal and adult stages of S. dichotomus. Different food sources showed different degrees of suitability: C. cephalonica significantly $(P<0.01)$ shortened the developmental period of nymphal and adult stages compared to T. molitor larvae and combination of both larvae by $17.5 \%$ and $6.9 \%$, respectively. Moreover, C. cephalonica larvae alone represent a more suitable food source for $1^{\text {st }}$ and $2^{\text {nd }}$ nymph instars development, compared to late nymphs and adults. However, the combination of both larvae had the shortest nymph's developmental period (95 days), higher body weight and longer femur length, plus improved the adults' longevity (69 days). The ratio of male adults was higher in the treatment which fed on T. molitor larvae and combination of both larvae, in contrast to the C. cephalonica larvae treatment. It is suggested that future works should examine the nutritional quality of the prey species to support these findings.
\end{abstract}

Keywords: Sycanus dichotomus, sycanus, reduviidae, generalist predator, bagworm, oil palm.

Date received: 11 January 2016; Sent for revision: 20 January 2016; Received in final form: 25 October 2016 ; Accepted: 26 October 2016.

\section{INTRODUCTION}

Oil palm is an important commodity crop in Malaysia, which covers 5.39 milion hectares of plantation areas in Malaysia, in 2014 (MPOB, 2015). When there is a breakdown in natural control, pest numbers increase, leading to outbreak. Bagworms (Metisa plana and Pteroma pendula) and nettle caterpillars (Darna spp. and Setora nitens) are major

Malaysian Palm Oil Board, 6 Persiaran Institusi,

Bandar Baru Bangi, 43000 Kajang, Selangor, Malaysia.

E-mail: nurulhidayah@mpob.gov.my insect pests of oil palm. These two bagworms species frequently damage the oil palm leaves, leading to serious crop losses (Basri, 1993). Biological control methods are favoured to suppress the bagworms and nettle caterpillars population, including beneficial plants for sustaining the parasitoids and predators, pheromone trapping (Norman et al., 2010) and application of biological insecticides (Siti Ramlah et al., 2011).

The majority of the assassin bugs (Reduviidae) are general insect predators with a wide variety of prey (Chandra et al., 2014). Several studies have shown that reduviid predators such as Sycanus 
sichuanensis Hsiao (Liu et al., 2012), Rhynocoris marginatus Fab. (Shahayaraj and Sathiamoorthi, 2002) and Phonoctonus spp. (Schaefer and Ahmad, 1987) are suitable as biological control agents for the nymphal and larval stages of insect pests. To date, the bionomics and use of Sycanus species for biological control have been reported such as S. croceovittatus for Dendrolimus punctatus, Latoia lepida, Scopelodes contracta, Artona funeralis and Selepa celtis (Kershaw, 1909; Hoffmann, 1934; Huang et al., 1991), S. indigator for Galleria mellonella and Spodopterafrugiperda (Bass and Shepard, 1974; Greene and Shepard, 1974), S. affinis for lepidopteran larvae in coconut groves (Satpathy et al., 1975), S. reclinatus for Heliothis armigera, Earias insulana, E. vitelli, Spodoptera litura and Dysdercus cingulatus (Vennison and Ambrose, 1992), S. versicolor for $H$. armigera and E. insulana (Kumaraswami and Ambrose, 1992), S. macracanthus for Mahasena corbetti and Setothosea asigna (Tiong, 1996) and S. aurantiacus for Plutella xylostella and Crocidolomia pavonana (Ishikawa et al., 2007; Yuliadhi et al., 2015).

Sycanus dichotomus Stal. (Hemiptera: Reduviidae) is a general predator that attacks bagworms and nettle caterpillars in oil palm plantations in Malaysia. Reported as one of the important predator for bagworms (De Chenon et al., 1989), they are commonly found at the ground level in oil palm plantations (Norman et al., 1998). The food sources may be a limiting factor for the effectiveness of predation by $S$. dichotomus as a biological control agent. Thus, evaluation on the alternative prey species is essential to measure the quality of the available food. The quality food may influence the growth and development of the predator and can be useful in future mass rearing. Previous studies showed that $S$. dichotomus can successfully develop and reproduce on a wide range of alternative prey larvae such as Plutella xylostella (Lepidoptera: Plutellidae), Corcyra cephalonica (Lepidoptera: Pyralidae) (Zulkefli et al., 2004) and Tenebrio molitor (Coleoptera: Tenebrionidae) (Syari et al., 2011; Yusof and Fairuz, 2011).

According to Symondson et al. (2002), generalist predators are polyphagous and can maintain their population on a wide range of alternative prey when any single pest species is absent. In agricultural systems, alternative prey may improve generalist predators' survival when target pests are occasional (Ehler and Miller, 1978; Eubanks and Denno, 2000). Fecundity can be increased and speed the development by providing additional nutrition (Halaj and Wise, 2002; Rana et al., 2002). Thus, alternative prey should be beneficial from the predator's perspective. Similarly, McMurtry (1992) revealed that the generalist phytoseiids (Mesostigmata: Phytoseiidae) are frequently observed for long periods on plants in the absence of prey and feed on alternative food.
Therefore, studying the potential alternative prey species for $S$. dichotomus is an important step in understanding the potential of the prey for future predator mass production in laboratory. The present study was undertaken to evaluate the effect of two alternative prey species and their combination as food sources on the developmental period, body weight and femur length of $S$. dichotomus. The preferred food sources could also be suggested by evaluating the growth parameter of $S$. dichotomus. In this study, the live larvae of C. cephalonica and T. molitor were chosen as food sources for $S$. dichotomus because they are commonly available in market, easy to rear and require simple maintenance in the laboratory.

\section{MATERIALS AND METHODS}

The study was conducted in the Entomology and Ecological Research Laboratory, Malaysian Palm Oil Board, Bandar Baru Bangi, Selangor, Malaysia. All insects rearing and experiments were conducted in an environment controlled room at day temperature of $27 \pm 1^{\circ} \mathrm{C}$, night temperature of $24 \pm 1^{\circ} \mathrm{C}$, with a photoperiod of 12:12 (L:D) hr and 50\%-70\% RH, monitored by a hygrothermograph (Dickson brand) (Siti Nurulhidayah et al., 2011).

\section{Insects Rearing}

Sycanus dichotomus. The predator, S. dichotomus adults were collected from various oil palm plantations in Teluk Intan, Perak, Malaysia and were maintained in the laboratory. The adults were paired and caged in a transparent cylinder container (measuring $12.5 \mathrm{~cm}$ diameter $\times 23.5 \mathrm{~cm}$ height) with a ventilated lid. Small ferns and oil palm leaflets were provided in the rearing container to simulate their concealed microhabitat and for egg laying. Oil palm leaflets were cut and placed through a hole in the transparent plastic lid of a glass vial containing water. The adults were fed daily with the mealworm, T. molitor larvae as food source and provided with $10 \%$ honey solution in a wet cotton ball. These cylinder containers were examined daily for occurrence of oviposition and eggs collection. The new eggs laid were then transferred to a petri dish until they hatched. The newly hatched nymphal stages were used for this study.

Tenebrio molitor. The mealworm, T. molitor was reared on sliced bread and oat bran in a plastic rearing container (measuring $20 \times 10 \times 12 \mathrm{~cm}$ ) while the adults were reared on oat bran and sliced fresh potato. The live larvae of T. molitor were used as food source for S. dichotomus.

Corcyra cephalonica. The rice moth, C. cephalonica was obtained from Universiti Putra Malaysia, 
Serdang, Selangor, Malaysia. A colony of C. cephalonica was reared on corn and rice in a plastic rearing container (measuring $25 \times 35 \times 12 \mathrm{~cm}$ ). Both cereals were ground separately. The ratio of corn to rice used was $1: 2$ and was autoclaved in $121^{\circ} \mathrm{C}$ for 20 min. Similarly, the live larvae of C. cephalonica was used as food source for $S$. dichotomus.

\section{Live Insect Larvae Suitability for S. dichotomus}

The influence of T. molitor larvae, C. cephalonica larvae and combination of both larvae on the individual growth of $S$. dichotomus was evaluated separately under the same rearing conditions. The suitability of live insect larvae as food sources for $S$. dichotomus was evaluated by measuring $S$. dichotomus developmental period, body weight and femur length for all stages after moulting to the next stage.

\section{Developmental Period, Body Weight and Femur Length of $S$. dichotomus}

Pre-imaginal developmental period was estimated by observing the $S$. dichotomus individuals on daily basis, from egg to emergence of the adult. The newly hatched nymphs were transferred from the petri dish with a soft brush and placed individually in a small plastic cup (measuring $6 \mathrm{~cm}$ diameter $\times 4.5 \mathrm{~cm}$ height). The nymphs were assigned to either T. molitor larvae, C. cephalonica larvae or combination of both larvae. A 10\% honey solution was also provided for each cage. After moulting to the $3^{\text {rd }}$ instar, the nymphs were transferred to a larger individual transparent cylinder cage (measuring $12.5 \mathrm{~cm}$ diameter $\times 23.5 \mathrm{~cm}$ height) with a ventilated lid. The live insect larvae consumed were replaced at two-day intervals. Mortality were also recorded at two-day intervals.

The period between moulting was used as a basis to calculate the developmental period for each nymphal instar of $S$. dichotomus. The life span of the $S$. dichotomus adult was determined from its emergence until it died. Its body weight and femur length was measured after each moult. The femur length measured was the hind femur, the thick and most muscular segment of the insect leg, situated between the trochanter and the tibia. The newly moulted nymphs were weighed individually using a Sartorius ED $224 S$ analytical balance with a precision of $10^{-5} \mathrm{~g}$. The same procedure was repeated until the $S$. dichotomus reached the adult stage.

\section{Longevity and Gender Ratio of S. dichotomus}

S. dichotomus adult individuals were placed in individual transparent cylinder cage (measuring $12.5 \mathrm{~cm}$ diameter $\times 23.5 \mathrm{~cm}$ height) with a ventilated lid to evaluate their longevity. The gender of
S. dichotomus can only be determined after the $5^{\text {th }}$ nymphal stage moulted to the adult stage. Individual adults were assigned to either $T$. molitor larvae, C. cephalonica larvae or combination of both larvae. A $10 \%$ honey solution was also provided for each cage. The adult weight at emergence was measured individually using a Sartorius ED 224S analytical balance. The main difference between the males and females of S. dichotomus is the abdomen shape. According to Syari et al. (2011), the female's abdomen is V-shaped while the male, U-shaped. The female size is also generally bigger and the abdomen is wider compared to the male. The sex ratio was recorded for adults which emerged on all treatments. Each adult was observed at two-day intervals to record its longevity.

\section{Statistical Analysis}

Experiments were replicated three times with 20 individuals in each treatment for each replication. Samples were first described as means and standard errors. Analyses of variance (ANOVA) were conducted on all data except gender ratio using SAS software (SAS 9.1 for Windows, 2003). Where statistical differences existed between the data sets $(\mathrm{P}<0.05)$, Fisher's Least Significant Difference (LSD) tests were used to separate the differing means.

\section{RESULTS AND DISCUSSION}

The developmental period, body weight and femur length for each life stages of $S$. dichotomus fed on the three categories of food sources were examined and varied in suitability to the food sources. In this study, three food categories given had relatively supported the growth and development of S. dichotomus but differ in terms of its developmental period, body weight and femur length. The total nymphal stage duration (95 days) for $S$. dichotomus fed on combination of both larvae was significantly shorter $(\mathrm{P}<0.01)$ compared to T. molitor (115 days) and C. cephalonica (98 days) larvae alone, by $21.3 \%$ and $2.8 \%$, respectively (Table 1 ). The mean life span of $S$. dichotomus fed on C. cephalonica larvae was significantly shorter $(\mathrm{P}<0.05)$ at 154 days, whereas $S$. dichotomus fed on T. molitor and combination of both larvae were significantly longer at 181 days and 164 days, respectively. Tenebrio molitor larvae ranked second due to longest duration during $5^{\text {th }}$ nymphal stage, resulted in an overall slower rate of predator's developmental period which caused an extended life span (Table 1).

After the $3^{\text {rd }}$ nymphal stage, the growth and development of $S$. dichotomus fed on $C$. cephalonica larvae had relatively decreased compared to other food sources, with exception of $5^{\text {th }}$ nymphal stage, in terms of body weight and femur length. However, 
TABLE 1. DEVELOPMENTAL PERIOD IN DAYS (mean \pm S.E.) OF S. dichotomus FED ON T. molitor LARVAE, C. cephalonica LARVAE AND COMBINATION OF BOTH LARVAE

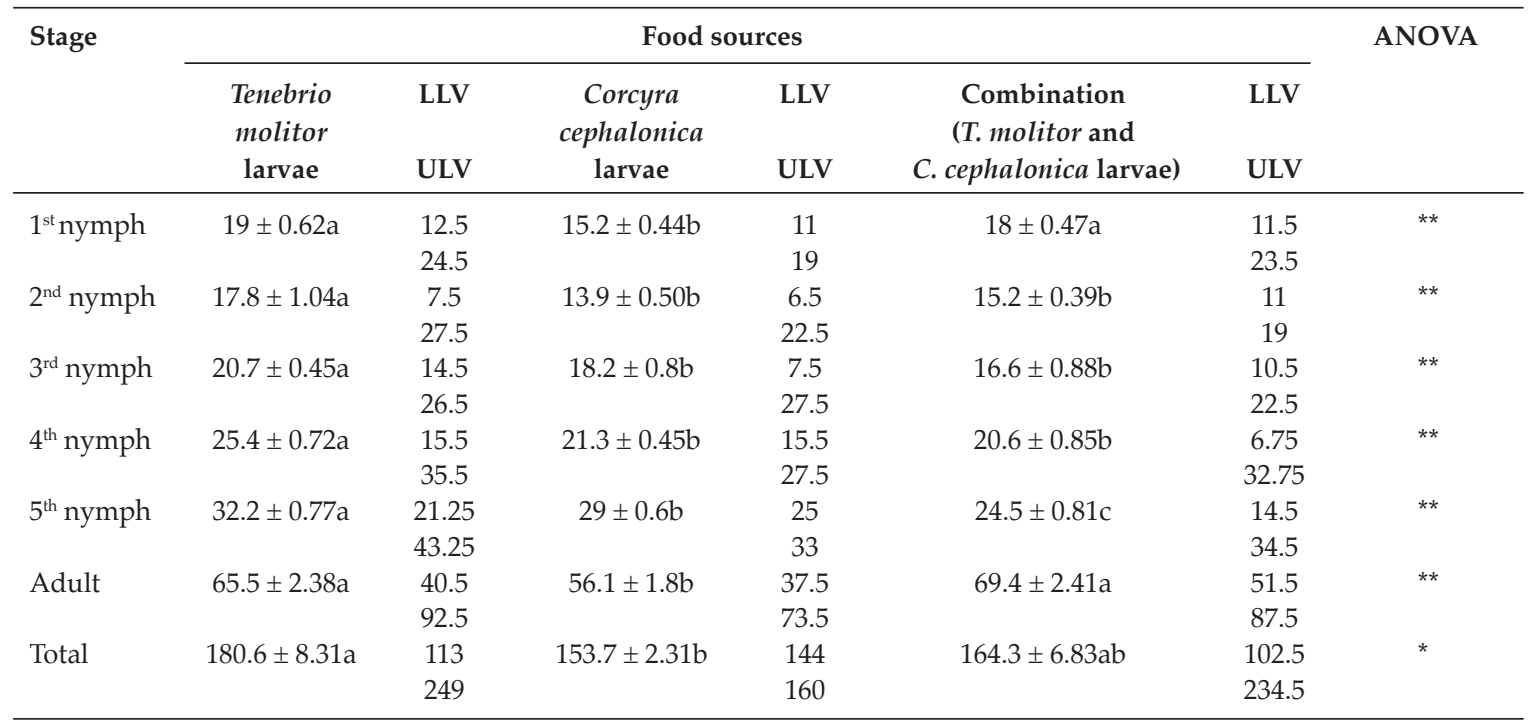

Note:

LLV - lower limit value.

ULV - upper limit value.

n.s. - not significant.

**Significant at $\mathrm{P}<0.01$.

* Significant at $\mathrm{P}<0.05$.

Different letters within a row indicate significant differences.

ANOVA - analysis of variance.

C. cephalonica represents a preferred diet for the $1^{\text {st }}$ and $2^{\text {nd }}$ nymphal stages based on the shorter nymphs' duration and higher body weight, but was not a suitable food source for the $3^{\text {rd }}$ nymphal stage to adults (Table 2). It was observed that the early nymphal stages can easily consume C. cephalonica because the outer skin of larvae are silky soft and easy to be penetrated by the younger predator compared to T. molitor larvae.

It was observed that the longest duration in survival within the life span was the adult stage. Regarding the adult longevity, there were significant differences between the food sources: adult life span was significantly longer when fed with the combination of both larvae as the food source (69.4 days) and shorter when fed with either T. molitor or C. cephalonica larvae alone (66 and 56 days, respectively) (Table 1). The longer adults' life span will possibly enhance the predation ability of the predator at its adult stage. Several studies have shown that food quality affects the developmental period and survival of several predators (Isikber and Copland, 2002; Kalushkov, 1998; Kalushkov and Hodek, 2004), as well as affecting the reproductive performance of the adults. In contrast, according to Vivan et al. (2003), the prolonged developmental period has been observed is an undesirable characteristic under field conditions, causing a lower number of generations per year, lower predator population growth, and hence reduced biocontrol efficiency.
Sycanus dichotomus fed with the combination of both insect larvae grew bigger in their body, shown in their weight (Table 2) and femur length (Table 3), with adults lived considerably longer and healthier. The adults reared with the combination of both larvae, tended to have higher weights than those reared on the C. cephalonica and T. molitor larvae alone, by $18.4 \%$ and $7.7 \%$, respectively. An earlier study by ElHag and Zaitoon (1996) have also observed higher survival rates of Coccinella undecimpunctata $(61.5 \%)$ when they used a mixed diet of two aphids, Brevicoryne brassicae L. and Rhopalosipum padi L. (Homoptera: Aphididae). With exception of the $1^{\text {st }}$ and $2^{\text {nd }}$ nymphal stages, the body weight of $S$. dichotomus that fed with combination of both larvae were significantly higher than those fed with T. molitor and $C$. cephalonica larvae alone (Table 2). The higher weight of nymphs achieved by the $3^{\text {rd }}, 4^{\text {th }}$ and $5^{\text {th }}$ nymph instars, when provided the combination of both larvae, reinforces the higher quality of this food category. According to Vivan et al. (2003) in their study, the $5^{\text {th }}$ nymphal instar of stinkbug Podisus nigrispinus (Dallas) (Heteroptera: Pentatomidae) have emphasised development of the reproductive organs, and this higher quality food group may affect the adult weight of $S$. dichotomus (Table 2). However, the mean body weight had differed significantly among the three food sources for all life stages except for the $1^{\text {st }}, 5^{\text {th }}$ nymphal instars and adults. 
Similarly, the mean femur length of the adult S. dichotomus fed with the combination of both larvae was significantly longer $(11.2 \mathrm{~mm})$ than those fed with $C$. cephalonica and T. molitor larvae alone $(\mathrm{P}<0.01)$ by $4.7 \%$ and $13.1 \%$, respectively (Table 3 ). This matched the significantly higher body weight gained by the combination of both larvae treatment for $3^{\text {rd }}$ and $4^{\text {th }}$ nymphal stages (Table 2). There was a significant difference among the three food sources in femur length parameter for all life stages except for the $1^{\text {st }}, 2^{\text {nd }}$ and $5^{\text {th }}$ nymph instars.

The sex ratio among all treatments was also observed (Figure 1). The male sex ratio was higher (5.8:4.2 and 7:3) in treatment which was fed with T. molitor larvae and combination of both larvae, respectively, while the female sex ratio was higher (9:1) when they were fed with C. cephalonica larvae. Thus, in all treatments, the body weight and life duration for females were always higher and longer than males. Similar trend was also observed in an earlier study conducted by Rana et al. (2002) on generalist ladybird beetle, Adalia bipunctata reared on Acyrthosiphon pisum and Aphis fabae.

Overall, the experiments revealed that the differing suitability for two types of live insect larvae as food sources for $S$. dichotomus. The assumption of the nutritional quality of different prey as food for generalist predators therefore contradicts with the results gathered. Similar results have been reported for other generalist predators such as Coccinella undecimpunctata (Coleoptera: Coccinellidae) and Clitostethus arcuatus (Rossi) (Coleoptera: Coccinellidae) (Cabral et al., 2006; Yazdani and Zarabi, 2011). The nutritional value might differ among the prey species. According to $\mathrm{O}^{\prime} \mathrm{Neil}$ and Wiedenmann (1990) in their insect predator study, Podisus maculiventris maintains its weight and reproductive output only when it has abundant prey. Reproduction can also be maintained on a diet of small prey, indicating the capacity

TABLE 2. BODY WEIGHT IN GRAM (mean \pm S.E.) OF S. dichotomus FED ON T. molitor LARVAE, C. cephalonica LARVAE AND COMBINATION OF BOTH LARVAE

\begin{tabular}{|c|c|c|c|c|}
\hline \multirow[t]{2}{*}{ Stage } & \multicolumn{3}{|c|}{ Food sources } & \multirow[t]{2}{*}{ ANOVA } \\
\hline & $\begin{array}{c}\text { Tenebrio molitor } \\
\text { larvae }\end{array}$ & $\begin{array}{c}\text { Corcyra cephalonica } \\
\text { larvae }\end{array}$ & $\begin{array}{c}\text { Combination (T. molitor } \\
\text { and } C \text {. cephalonica larvae) }\end{array}$ & \\
\hline $1^{\text {st }}$ nymph & $0.0017 \pm 0.0012 \mathrm{a}$ & $0.0019 \pm 0.0002 a$ & $0.0018 \pm 0.0002 a$ & n.s. \\
\hline $2^{\text {nd }}$ nymph & $0.0019 \pm 0.0002 b$ & $0.0051 \pm 0.0003 a$ & $0.0046 \pm 0.0003 a$ & $* *$ \\
\hline $3^{\text {rd }}$ nymph & $0.0278 \pm 0.0012 b$ & $0.018 \pm 0.0010 c$ & $0.0412 \pm 0.0026 a$ & $* *$ \\
\hline $4^{\text {th }}$ nymph & $0.0706 \pm 0.0013 b$ & $0.0656 \pm 0.0021 b$ & $0.1227 \pm 0.0042 a$ & $* *$ \\
\hline $5^{\text {th }}$ nymph & $0.1427 \pm 0.0022 \mathrm{a}$ & $0.1512 \pm 0.0050 \mathrm{a}$ & $0.1668 \pm 0.0179 a$ & n.s. \\
\hline Adult & $0.2047 \pm 0.0057 a$ & $0.1862 \pm 0.0192 a$ & $0.2204 \pm 0.0115 a$ & n.s. \\
\hline
\end{tabular}

Note:

n.s - not significant.

** Significant at $\mathrm{P}<0.01$.

* Significant at $\mathrm{P}<0.05$.

Different letters within a row indicate significant differences.

ANOVA - analysis of variance.

TABLE 3. FEMUR LENGTH IN MILLIMETER (mean \pm S.E.) OF s. dichotomus FED ON T. molitor LARVAE, C. cephalonica LARVAE AND COMBINATION OF BOTH LARVAE

\begin{tabular}{|c|c|c|c|c|}
\hline \multirow[t]{2}{*}{ Stage } & \multicolumn{3}{|c|}{ Food sources } & \multirow[t]{2}{*}{ ANOVA } \\
\hline & $\begin{array}{c}\text { Tenebrio molitor } \\
\text { larvae }\end{array}$ & $\begin{array}{c}\text { Corcyra cephalonica } \\
\text { larvae }\end{array}$ & $\begin{array}{c}\text { Combination (T. molitor } \\
\text { and C. cephalonica larvae) }\end{array}$ & \\
\hline $1^{\text {st }}$ nymph & $1.04 \pm 0.04 a$ & $1.12 \pm 0.04 a$ & $1.08 \pm 0.04 a$ & n.s. \\
\hline $2^{\text {nd }}$ nymph & $1.71 \pm 0.06 \mathrm{ab}$ & $1.6 \pm 0.07 b$ & $1.74 \pm 0.05 a$ & n.s. \\
\hline $3^{\text {rd }}$ nymph & $4.25 \pm 0.12 b$ & $3.7 \pm 0.11 c$ & $5.12 \pm 0.09 a$ & $* *$ \\
\hline $4^{\text {th }}$ nymph & $6.91 \pm 0.14 a$ & $5.95 \pm 0.17 b$ & $6.64 \pm 0.1 \mathrm{a}$ & $* *$ \\
\hline $5^{\text {th }}$ nymph & $9.55 \pm 0.24 \mathrm{ab}$ & $9.1 \pm 0.2 b$ & $9.8 \pm 0.13 a$ & n.s. \\
\hline Adult & $10.7 \pm 0.1 b$ & $9.9 \pm 0.25 c$ & $11.2 \pm 0.13 a$ & $* *$ \\
\hline
\end{tabular}

Note:

n.s - not significant.

${ }^{* *}$ Significant at $\mathrm{P}<0.01$.

*Significant at $\mathrm{P}<0.05$.

Different letters within a row indicate significant differences.

ANOVA - analysis of variance. 


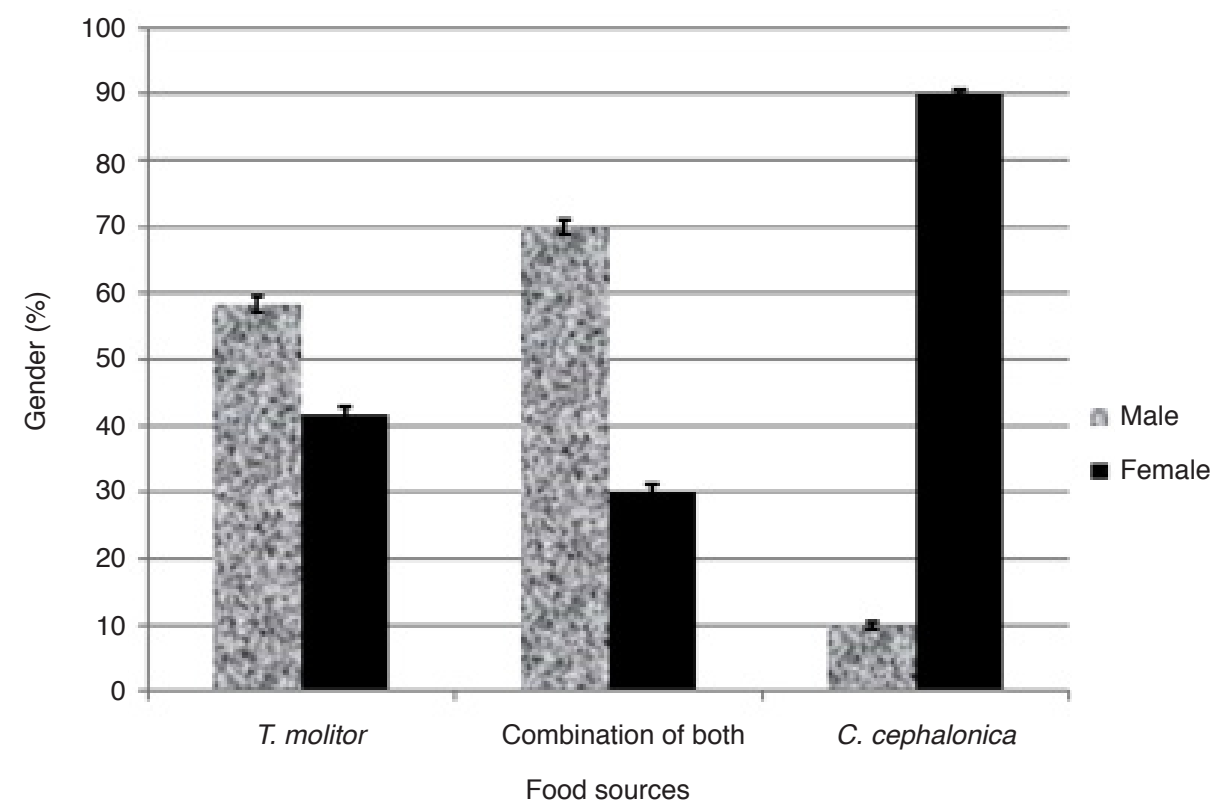

Figure 1. The gender percentage of Sycanus dichotomus fed on different larvae treatments.

for flexible foraging and proficient extraction of nutrients (Mills, 1982). The presence of low quality prey species may therefore counteract the benefits of mixed food sources for the predators. The performance, in terms of the parameters measured, was better when the predators were fed on combined prey than on single prey, especially during the nymphs' development.

It was also observed that the $1^{\text {st }}$ and $2^{\text {nd }}$ nymphal stages of $S$. dichotomus developmental period were much longer when fed with T. molitor larvae than other diets (Table 2), possibly due to the inability of young nymphs to penetrate the T. molitor larva's cuticle with their rostrum. In the combined diet treatment, we observed that the $1^{\text {st }}$ and $2^{\text {nd }}$ nymphal stages preferred to consume on C. cephalonica larvae rather than T. molitor larvae. In terms of developmental period and body weight, S. dichotomus fed with C. cephalonica were relatively shorter and higher. Thus, it can be concluded that C. cephalonica larvae were the preferred prey for early nymphal stages of $S$. dichotomus. The suitability of different prey types as food sources for the predators could be varied. Many predatory insects appear opportunistic in the field, feed on a wide range of prey species, but this behaviour may not clearly indicate prey suitability and predator nutritional requirements (Thompson, 1951; Thompson and Hagen, 1999). Predator diet specificity, feeding preferences and capacity for population increases are the factors that largely depend on prey suitability (Dixon, 2000).

Nevertheless, the developmental and reproductive performance of $S$. dichotomus fed on combination of both larvae need to be assessed over subsequent generations. This is because the nutritional imbalances within the diet are possibly expressed only in the subsequent generations (De Clercq et al., 2005), similarly suggested by Nguyen et al. (2013) in their predatory mite, Amblyseius swirskii study.

\section{CONCLUSION}

The study of developmental period, body weight, femur length of each life stage, as well as longevity and gender of adults with live larvae of T. molitor, C. cephalonica and their combination allows the evaluation of the suitability of the food sources. This finding indicates that $S$. dichotomus can enhance its growth and development if adapted to combination of both larvae compared to two other single prey species, especially during nymphal stages. Thus, combination of both larvae diet is more suitable to be used as one of food candidates in S. dichotomus mass rearing system. It was indicated that the alternative prey as food sources has shown potential to the mass production of this economically important biological control agent.

\section{ACKNOWLEDGEMENT}

The authors thank the Director-General of MPOB for permission to publish this article. A round of thanks to the staff of Entomology \& Ecological Research Laboratory, Biological Research Division, MPOB, particularly Othman Arshad, Hajijah Shamsuddin, Noorhasan Mohd Yob, Mat Tahir Bong Ruziz, Zuriahti Khamis and Tunku Akhirudin Tunku Aris for their help in conducting the experiments. Thanks are also extended to Zulkefli Masijan for helpful advice and comments. 


\section{REFERENCES}

BASRI, M W (1993). Life History, Ecology and Economic Impact of the Bagworm, Metisa plana Walker (Lepidoptera: Psychidae), on the Oil Palm Elaeis guineensis Jackquin (Palmae) in Malaysia. Ph.D thesis, University of Guelph. 231 pp.

BASS, J A and SHEPARD, M (1974). Predation by Sycanus indagator on larvae of Galleria mellonella and Spodoptera frugiperda. Entomologia Experimentalis et Applicata, 17: 143-148.

CABRAL, S;SOARES, AO;MOURA, R and GARCIA, P (2006). Suitability of Aphis fabae, Myzus persicae (Homoptera: Aphididae) and Aleyrodes proletella (Homoptera: Aleyrodidae) as prey for Coccinella undecimpunctata (Coleoptera: Coccinellidae). Biological Control, 39: 434-440.

CHANDRA, K; KUSHWAHA, S; BISWAS, B and MUKHERJEE, P (2014). Assassin bugs (Reduviidae: Hemiptera) from Madhya Pradesh, India. J. Entomology and Zoology Studies, 2(1): 38-50.

DE CHENON, D R; SIPAYUNG, A and SUDHARTO, PS (1989). The importance of natural enemies on leaf eating caterpillar in oil palm in Sumatra, Indonesia uses and possibilities. Proc. of the PORIM International Palm Oil Development Conference. PORIM, Bangi. 5-9 September 1989. p. 245-262.

DE CLERCQ, P; ARIJS, Y; VAN MEIR, T; VAN STAPPEN, G; SORGELOOS, P; DEWETTINCK, K; REY, M; GRENIER, S and FEBVAY, G (2005). Nutritional value of brine shrimp cysts as a factitious food for Orius laevigatus (Heteroptera: Anthocoridae). Biocontrol Science and Technology, 15: 467-479.

DIXON, A F G (2000). Insect Predator - Prey Dynamics: Ladybirds and Biological Control. Cambridge University Press, Cambridge, MA.

EHLER, L E and MILLER, J C (1978). Biological control in temporal agroecosystems. Entomophaga, 23: 207-212.

ELHAG, E T A and ZAITOON, AA (1996). Biological parameters for four coccinellid species in Central Saudi Arabia. Biological Control, 7: 316-319.

EUBANKS, M D and DENNO, R F (2000). Host plants mediate ominivore - herbivore interactions and influence prey suppression. Ecology, 81: 936-947.

GREENE, G L and SHEPARD, M (1974). Biological studies of a predator Sycanus indagator. II. Field survival and predation potential. Florida Entomologist, 57: 33-38.
HALAJ, J and WISE, D H (2002). Impact of a detrital subsidy on trophic cascades in a terrestrial grazing food web. Ecology, 83: 3141-3151.

HOFFMANN, W E (1934). Biology of Sycanus croceovittatus Dohrn (Hemiptera: Reduviidae). Lingnan Science J., 13: 505-515.

HUANG, Z; WU, J and ZHANG, Z (1991). A preliminary study on the bionomics and application of Sycanus croceovittatus. Forest Research, 1: 58-64.

ISIKBER, A A and COPLAND, M J W (2002). Effects of various aphid foods on Cycloneda sanguinea. Entomologia Experimentalis et Applicata, 102: 93-97.

ISHIKAWA, T; TORIUMI, W; SUSILA, W and OKAJIMA, S (2007). Sycanus aurantiacus (Hemiptera: Heteroptera: Reduviidae), a new harpactorine species from Bali, Indonesia, with brief notes on its biology. Zootaxa, 1615: 21-27.

KALUSHKOV, P (1998). Ten aphid species (Sternorrhyncha: Aphidae) as prey for Adalia bipunctata (Coleoptera: Coccinellidae). European J. Entomology, 95: 343-349.

KALUSHKOV, P and HODEK, I (2004). The effects of thirteen species of aphids on some life history parameters of the ladybird Coccinella septempunctata. BioControl, 49: 21-32 1984-1092.

KERSHAW, J C W (1909). On the metamorphosis and anatomy of the reduviid bug Sycanus croceovitatus Dohrn. Bulletin et Annales de la Societe Royale Belge d'Entomologie. 53: 241-249.

KUMARASWAMI, N S and AMBROSE, D P (1992). Biology and prey preference of Sycanus versicolor Dohrn (Hemiptera: Reduviidae). J. Biological Control, 6: 67-71.

LIU, H; LI, H; YU, C; TADAUCHI, O and CAI, W (2012). Taxonomic and bionomic notes on Sycanus sichuanensis Hsiao (Hemiptera: Reduviidae: Harpactorinae). J. Faculty of Agriculture, 57(1); 73 77.

MCMURTRY, J A (1992). Dynamics and potential impact of 'generalist' phytoseiids in agroecosystems and possibilities for establishment of exotic species. Experimental and Applied Acarology, 14: 371-382.

MILLS, N J (1982). Satiation and the functional response: a test of a new model. Ecological Entomology, 7: 305-315.

MPOB (2015). Malaysia Oil Palm Statistics. 34 ${ }^{\text {th }}$ Edition. MPOB, Bangi. 212 pp. 
NGUYEN, D T; VANGANSBEKE, D; LU", $\mathrm{X}$ and DE CLERCQ, P (2013). Development and reproduction of the predatory mite Amblyseius swirskii on artificial diets. Biocontrol, 58: 369-377.

NORMAN, K; BASRI, $\mathrm{M} \mathrm{W}$ and ZULKEFLI, M (1998). Handbook of Common Parasitoid and Predator Associated with Bagworm and Nettle Caterpillar in Oil Palm Plantations. PORIM, Bangi. 29 pp.

NORMAN, K; SITI NURULHIDAYAH, A and BASRI, M W (2010). Pheromone mass trapping bagworm moths (Metisa plana, Lepidoptera: Psychidae) for its control in mature oil palms in Perak, Malaysia. J. Asia-Pacific Entomology, 13: 101106.

O'NEIL, R J and WIEDENMANN, R N (1990). Body weight of Podisus maculiventris (Say) under various feeding regimes. Canadian Entomologist, 122: 285294.

RANA, J S; DIXON, A F G and JAROSIK, V (2002). Costs and benefits of prey specialization in a generalist insect predator. J. Animal Ecology, 71: 1522.

SAS (2003). SAS 9.1 for Windows.

SATPATHY, J M; PATNAIK, N C and SAMALO, A $R$ (1975). Observations on the biology and habits of Sycanus affinis Reuter (Hemiptera: Reduviidae) and its status as a predator. J. Bombay Natural History Society, 72: 589-595.

SCHAEFER, C W and AHMAD, I (1987). Parasites and predators of Pyrrhocoroidea (Hemiptera) and possible control of cotton stainers by Phonoctonus spp. (Hemiptera: Reduviidae). Entomophaga, 32: 269275.

SHAHAYARAJ, J and SATHIAMOORTHI, P (2002). Influence of different diets of Corcyra cephalonica on life history of a reduviid predator Rhynocoris marginatus (Feb.). J. European Agriculture, 3(1): 53- 61.

SITI NURULHIDAYAH, A; NORMAN, $\mathrm{K}$ and ZULKEFLI, M (2011). Mixed prey as a food source for mass rearing of the bagworm predator, Sycanus dichotomus. MPOB Information Series No. 559.

SITI RAMLAH AHMAD ALI; RAMLE MOSLIM; NORMAN KAMARUDIN and MOHD BASRI WAHID (2011). Microbial approach in pest control. Further Advances in Oil Palm Research (2000-2010) (Mohd Basri Wahid; Choo Yuen May and Chan Kook Weng eds.). MPOB, Bangi. p. 435-484.

SYARI, J; MUHAMAD, R; NORMAN, K and IDRIS, A B (2011). Pemeliharaan Sycanus dichotomus Stal.
(Hemiptera: Reduviidae) Serangga Pemangsa Ulat Bungkus Tanaman Sawit, Metisa plana (Lepidoptera: Psychidae) Walker di Makmal. Sains Malaysiana, 40 (10): $1129-1137$.

SYMONDSON, W O C; SUNDERLAND, K D and GREENSTONE, M H (2002). Can generalist predators be effective biocontrol agents? Annual Review of Entomology, 47: 561-594.

THOMPSON, S N and HAGEN, KS (1999). Nutrition of entomophagous insects and other arthropods. Handbook of Biological Control (T S Bellows and T W Fisher, eds.). Academic Press, New York. p. 594-638.

THOMPSON, W R (1951). The specificity of host relationships in predaceous insects. Canadian Entomologist, 83: 262-269.

TIONG, R (1996). The regulatory roles of natural enemies of some oil palm insect pests. The Planter, 72: 653-666.

VENNISON, S J and AMBROSE, D P (1992). Biology, behaviour and biocontrol efficiency of a reduviid predator, Sycanus reclinatus Dohrn (Heteroptera: Reduviidae) from southern India. Mitteilungen aus dem Museum für Naturkunde Berlin, 68: 143-156.

VIVAN, L M; TORRES, J B and VEIGA, A F S L (2003). Development and reproduction of a predatory stinkbug, Podisus nigrispinus, in relation to two different prey types and environmental conditions. BioControl, 48: 155-168.

YAZDANI, $M$ and ZARABI, M (2011). The effect of diet on longevity, fecundity, and the sex ratio of Clitostethus arcuatus (Rossi) (Coleoptera: Coccinellidae). J. Asia-Pacific Entomology, 14: 349352.

YULIADHI, KA; SUPARTHA, I W; WIJAYA, I N and PUDJIANTO (2015). Characteristic morphology and biology of Sycanus aurantiacus Ishikawa et Okajima, sp. nov. (Hemiptera: Reduviidae) on the larvae of Tenebrio molitor L. (Coleoptera: Tenebrionidae). J. Biology, Agriculture and Healthcare, 5(10): 5-9.

YUSOF, I and FAIRUZ, M O (2011). Demographic parameters reproductive performance of the assassin bug Sycanus dichotomus Stal. fed on mealworm Tenebrio molitor L. J. Oil Palm Res. Vol. 26: 974-978.

ZULKEFLI, M; NORMAN, $\mathrm{K}$ and BASRI, $\mathrm{M}$ W (2004). Life cycle of Sycanus dichotomus (Hemiptera: Pentatomidae) - a common predator of bagworm in oil palm. J. Oil Palm Res.Vol. 16(2): 50-56. 